\title{
POLYPHENOLS AND CAFFEINE OF GREEN AND ROASTED COFFEE BEANS, AS NATURAL ANTIOXIDANTS \\ Tadros, L.K. ${ }^{1}$; Safaa M. Ali ${ }^{1}$; M. I. Sanad ${ }^{1}$; A.A. El-Sharkawy ${ }^{2}$ and A.K. Ahmed ${ }^{2}$ \\ 1- Dept. of Agric. Chem., Fac. Agric., Mans. Univ., Mans., Egypt. \\ 2- Food Tech. Res. Inst., Agric. Res. Cent., Dokki, Giza, Egypt.
}

\section{ABSTRACT}

Green, light, medium and dark roasted coffee beans were used in the powder form to identify polyphenols by HPLC. Eleven components were identified in green, light and dark coffee roasted powder. Para Coumaric, Ferulic, Salicylic and Cinnamic acids were absent in medium roasted coffee powder. Polyphenol extract was more effective for the inhibition of lipid peroxidation than caffeine and mixture of polyphenols and caffeine. Antioxidant capacity by 2,2-azino-bis (3ethylbenzothiazoline-6-sulfonic acid cation radical $\left(\mathrm{ABTS}^{+}\right)$showed a higher percentage of inhibition for polyphenols of green coffee $(86.09 \%)$ than light $(82.67$ $\%)$, medium (81.14\%) and dark (79.43\%). Caffeine of dark coffee samples has the lowest value of inhibition (72.0 \%) followed by medium coffee sample $(72.95 \%)$ then light sample $(75.05 \%)$, finally the green coffee sample $(77.34 \%)$. It seems that oxidative activity was affected with two factors: temperature and period of roasting.

\section{INTRODUCTION}

Antioxidants play an important role in preventing or delaying autooxidation and have attracted a lot of attention as food additives. Both synthetic and natural antioxidants are widely used in many food products. Natural antioxidants have been developed since past decade, mainly because of the increasing limitations on the use of synthetic antioxidants. In general, natural antioxidants are prefered than synthetic ones because of their safety and friendship to the environment. There has been a growing interest in replacing them with natural ingredients because of the toxicity of synthetic antioxidants. Now, it is well known that the use of some common synthetic antioxidants such as butylated hydroxy anisole (BHA) and butylated hydroxy toluene $(\mathrm{BHT})$ has become controversial issue because of adverse toxological effect. Hence, in recent years, the evaluation of antioxidative activity of naturally occurring substances has been of interest (Imaida et al., 1983).

The coffee plant belongs to the genus of Coffea (Rubiaceae family). Coffee is a giant global industry and ranks second only to petroleum in terms of dollars traded worldwide. Presently, coffee production is about 6.3 million tons, with Brazil and Colombia contributing to nearly $44 \%$ of these figures (Madhava Naidu et al., 2008).

Coffee is known to be a rich source of compounds with potent antioxidant activity. In a study performed with rats, it was observed that feeding rats with coffee brew resulted in an increase of the total antioxidant capacity of the plasma (Somoza et al., 2003).

A major contributor to the antioxidant activity was identified as $\mathrm{N}$ Methylpyridinium, a recently discovered alkaloid that is present in roasted coffee in concentrations of up to $0.25 \%$ on a dry weight basis (Stadler et al., 
2002). Moreover, coffee consumption has been associated with reduced incidences of several types of cancer (Leitzmann et al., 2007); Tavani and La-Vecchia, 2000), liver Cirrhosis (Tverdal and Skurtveit, 2003) and type 2 diabetes (Van Dam and Feskens, 2002). The antioxidant capacity of coffee has been attributed to its content of polyphenols and melanoidins (Anese and Nicoli, 2003; Delgado-Andrade and Morales, 2005 and Yen et al., 2005). Acrylamide and melanoidins are both Maillard reaction products (MRPs) formed during the roasting of coffee, typically conducted at temperatures between 220 and $250{ }^{\circ} \mathrm{C}$. Theoretically, any attempt to inhibit the Maillard reaction as a possible measure to minimize the formation of acrylamide would lead to a reduction of the antioxidant capacity of coffee (Summa et al., 2006).

More intense roasting, i.e. greater thermal load, of coffee beans has been considered as a way to decrease the concentration of acrylamide in coffee, albeit with a major impact on the organoleptic properties and consequently acceptability of the product. However, the reduction in the concentration of acrylamide with darker degrees of roasting is accompanied by a reduction of the radical scavenging capacity of coffee. Furthermore, temperature, time and the speed at which coffee is roasted have an important impact on the organoleptic properties of coffee and under extreme conditions could generate other "undesirable" compounds. In this study, a trial was carried out to identify and determine the major components of polyphenols in green, light, medium and dark coffee beans. Also, radical scavenging activity was expressed as the inhibition percentage. Separated caffeine, polyphenol and mixture of both, in different concentrations, were used to retard the autooxidation of sunflower oil.

\section{MATERIALS AND METHODS}

\section{Sampling}

1-Green coffee sample was purchased from local market.

2-Light roasted coffee powder: green coffee $(0.5 \mathrm{~kg})$ was roasted at $160{ }^{\circ} \mathrm{C}$ for 2 hrs. and milled, at the Laboratory. of Agric. Chem., Fac. of Agric., Mansoura Univ.

3-Medium roasted coffee powder: green coffee $(0.5 \mathrm{~kg})$ was roasted at $160{ }^{\circ} \mathrm{C}$ for $5 \mathrm{hrs}$. exactly as described before.

4-Dark roasted coffee powder (commercial sample): green coffee $(0.5 \mathrm{~kg})$ was roasted and milled in the market by their own procedure.

\section{Routine analysis:}

Moisture, ash, protein, lipid and carbohydrates contents for all samples were determined according to the method of A.O.A.C. (2000).

\section{Reliminary phytochemical tests:}

Preliminary phytochemical tests were carried out on the samples under investigation, to detect the presence of terpenes, tannins, flavonoids, saponins, alkaloids, carbohydrates, phenolic glucosides and resins as reported by Harborne (1988). 
Identification of polyphenols by HPLC:

Phenolic compounds of the forementioned samples were extracted according to the method of Ben-Hammouda et al. (1995). Identification of individual phenolic compounds were performed on a Hewlett-Packard HPLC (Model 1100). Eleven standard phenolic compounds were used namely Catechin, P-hydroxy benzoic acid, Chlorogenic acid, Caffeic acid, Syringic acid, Caffeine, Vanillic acid, P-Coumaric acid, Ferulic acid, Salicylic acid and Cinnamic acid were obtained from Sigma (st. Louis, USA) and MerckSchuchardt (Munich, Germany). Reagents and solvents used were specific for HPLC spectral grade.

\section{Evaluation of antioxidant activity of caffeine and polyphenols of coffee bean samples:}

Caffeine and polyphenols of green coffee beans, light, medium and dark were extracted using the method of A.O.A.C. (2000) for caffeine and the method of Singleton and Rossi (1965) for polyphenols. Separated samples of caffeine, polyphenols and mixture of caffeine and polyphenols in the ratio of $1: 1(\mathrm{wt} / \mathrm{wt})$ were used for the evaluation of antioxidative activity by two means:

\section{Determination of antioxidant capacity by 2,2-azino-bis(3-} ethylbenzothiazoline-6-sulfonic acid) cation radical $\left(\mathrm{ABTS}^{+}\right)$:

$\mathrm{ABTS}^{+}$assay based on the method of $\mathrm{Re}$ et al. (1999) with slight modifications. ABTS solution was added to $\mathrm{MnO}_{2}$ solution, then shaked and centrifuged for $10 \mathrm{~min}$., clear supernatant was separated. Investigated samples were prepared (separately) as follow:

Exactly $1 \mathrm{mg}$ of methanolic extract (ME) was dissolved in mixture of methanol and phosphate buffer $0.1 \mathrm{M}, \mathrm{pH} 7.0$ in the ratio of $1: 1$. Resultant solution $(20 \mu \mathrm{l})$ was added to $\mathrm{ABTS}^{+}$solution, as described before. Blank sample was prepared exactly in the same manner but differ only in the addition of $20 \mu \mathrm{l}$ of $2 \mathrm{mM}$ ascorbic acid, instead of investigated sample-buffer solution.

Absorbance of resulting green-blue color was measured at $734 \mathrm{~nm}$. Decrease in absorbance is expressed as a percentage of inhibition which was calculated from the following equation:

$$
\% \text { Inhibition }=\frac{A_{\text {Blank }}-A_{\text {Test }}}{A_{\text {Blank }}}
$$

Effect of caffeine, polyphenols and their mixture on the stability of sunflower oil:

Extracted caffeine, polyphenols or a mixture of them were added separately to sunflower oil in concentrations of 1000,3000 and 6000 ppm. The experiments were carried out as follows:

Exactly $25 \mathrm{~g}$ of crude sunflower oil sampls were placed in $120 \times 30 \mathrm{~mm}$ Petri dishes and the calculated ppm values were added to each oil sample and well stirred to ensure uniform distribution in the oil. Another experiment was performed using the synthetic antioxidant $100 \mathrm{ppm}$ BHT. A control 
Tadros, L.K. et al.

experiment (sunflower oil without any addition) was also conducted in the same manner.All samples were incubated at $60^{\circ} \mathrm{C}$ (Alaiz et al., 1995) for 20 days. Peroxide values (PV) were determined daily to measure the stability of oil samples according to IUPAC (1987).

Protection index $(\mathrm{Pl})$ was calculated according to the following equation (Alaiz et al., 1995):

$$
\mathrm{PI}=100-\left[100\left(\mathrm{PV}_{\mathrm{ME}}-\mathrm{PV}_{\mathrm{BHT}}\right) /\left(\mathrm{PV}_{\text {control }}-\mathrm{PV}_{\mathrm{BHT}}\right)\right]
$$

Where: $\mathrm{PV}_{\mathrm{ME}}, \mathrm{PV}_{\mathrm{BHT}}$ and $\mathrm{PV}_{\text {control }}$ are peroxide values of treated oils with $\mathrm{ME}$, $\mathrm{BHT}$ and control sample, respectively.

\section{RESULTS AND DISCUSSION}

\section{Chemical composition of green and roasted coffee beans:}

Samples under investigation were used for the determination of: moisture, ash, protein, lipid, total carbohydrates and caffeine. The proximate composition of green and roasted coffee beans is shown in Table (1). Moisture of green coffee samples represents approximately $11.52 \%$ with the highest value for the green sample and the lowest value for the dark sample. Moisture levels are within the range of $8.5-13.0 \%$ as reported by Clarke (1985). After roasting moisture levels decreased to an average of 3.85, 2.15 and $1.63 \%$ for light, medium and dark coffee powder, respectively. Ash contents were 5.15, 5.68, 5.98 and $5.63 \%$ for green, light, medium and dark coffee respectively. Protein levels for green coffee sample were $15.93 \%$, $16.19 \%$ for light coffee, $17.96 \%$ for medium and $16.84 \%$ for dark coffee powder. These values are within the range of $11.0-16.5 \%$ as reported by Macrae (1985) and Oliveira et al., (2006). Difference in protein levels may be due to the difference in moisture contents as described before. It is worthy to state that these results were based on the determination of crude nitrogen, so they include caffeine and other nitrogenous compounds. The lipid contents were found to be different among green, light, medium and dark coffee. Medium and dark coffee powder had higher oil contents than those of light and green coffee. The lipid contents ranged from $9-15 \%$ as stated in literature (Turatti, 2001 and Oliveira et al., 2006). Total carbohydrates were ranged between 53.5 and $60.00 \%$ as shown in Table (1). From the same table caffeine was represented 1.37, 1.47, 1.55 and $1.97 \%$ for green, light, medium and dark coffee, respectively. These levels of caffeine were in agreement with those obtained by Paulo Mazzafera (1999). Differences in the levels of caffeine may be due to differences of moisture contents.

Table (1): Some chemical composition content (gm/100g dry basis).

\begin{tabular}{|l|c|c|c|c|}
\hline Some chemical composition Sample & \multirow{2}{*}{ Green } & & \multicolumn{3}{|c|}{ Roasted coffee beans } \\
\cline { 3 - 5 } & & Light & Medium & Dark \\
\hline Moisture & 11.52 & 3.85 & 2.15 & 1.63 \\
\hline Ash & 5.15 & 5.68 & 5.98 & 5.63 \\
\hline Protein & 15.93 & 16.19 & 17.96 & 16.84 \\
\hline Lipid & 13.91 & 15.15 & 16.67 & 15.91 \\
\hline Total carbohydrate & 53.50 & 59.14 & 57.24 & 60.00 \\
\hline Caffeine & 1.37 & 1.47 & 1.55 & 1.97 \\
\hline
\end{tabular}




\section{Preliminary phytochemical tests:}

Obtained data indicated the presence of terpenes, tannins, flavonoids, alkaloids, carbohydrates, phenolic glycosides, polyphenolic compounds and caffeine. On the other hand, saponins and resins were absent in all samples as shown in table (2).

Table (2): The preliminary phytochemical tests of crude methanolic extract of coffee beans.

\begin{tabular}{|c|c|c|c|c|c|c|c|c|c|c|c|}
\hline Sample & Tests & 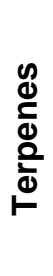 & 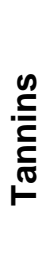 & $\begin{array}{l}\frac{9}{0} \\
\frac{0}{0} \\
\frac{0}{0} \\
\frac{\pi}{4} \\
\frac{\pi}{4}\end{array}$ & 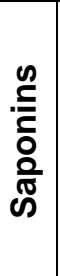 & $\begin{array}{l}\frac{0}{0} \\
\frac{0}{0} \\
\frac{0}{\mathfrak{N}} \\
\frac{\grave{y}}{\alpha}\end{array}$ & 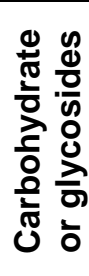 & 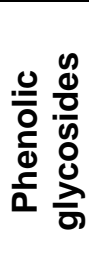 & 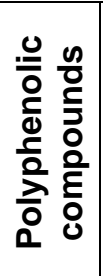 & 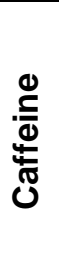 & 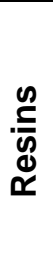 \\
\hline Green & & + & + & + & - & + & + & + & + & + & - \\
\hline Light & & + & + & + & - & + & + & + & + & + & - \\
\hline Medium & & + & + & + & - & + & + & + & + & + & - \\
\hline Dark & & + & + & + & - & + & + & + & + & + & - \\
\hline
\end{tabular}

\section{Identification of polyphenols of investigated samples using HPLC technique:}

Technique of HPLC was used for identification and determination of polyphenolic compounds in coffee beans (green, light, medium and dark roasted samples).

Eleven polyphenolic compounds were available as authentic samples namely Catechin, Caffeine, P-hydroxy benzoic, Chlorogenic, Caffeic, Syringic, Vanillic, Coumaric, Ferulic, Salicylic and Cinnamic acids.

Obtained data revealed that 25, 26, 27 and 25 compounds with different retention times were detected in HPLC chromatograms of green coffee beans, light, medium and dark roasted samples, respectively.

Table (3) indicated clearly that all investigated samples contained Catechin, Caffeine, P. hydroxy benzoic, Chlorogenic, Caffeic, Syringic and Vanillic acids with different concentrations. From the same table it could be noticed that P. Coumaric, Ferulic, Salicylic and Cinnamic acids were found in green and roasted coffee at the market and also in the roasted light sample, while they were absent in the medium roasted sample. This absence of previous mentioned compounds may be attributed to the effect of roasting time (5 hrs.) as reported by Sacchetti et al., (2009); Parliment (2000); Steinhart et al., (2002) and Duarte et al., (2005). They concluded that polyphenols content was observed decreasing with roasting. It is worthy to mention here that, dark roasted coffee bean sample obtained from the local market was prepared by heating at higher temperature for shorter time.

Also, Del Castillo et al. (2002) found that, during the roasting process, the naturally occurring polyphenol constituents are transformed to a complex mixture of Maillard reaction products. 
Tadros, L.K. et al.

Table (3): Identification of polyphenols of green, light, medium and dark roasted coffee beans using HPLC technique.

\begin{tabular}{|c|c|c|c|c|c|c|c|c|}
\hline \multirow{3}{*}{ Components } & \multirow{2}{*}{\multicolumn{2}{|c|}{ Green }} & \multicolumn{6}{|c|}{ Roasted coffee beans } \\
\hline & & & \multicolumn{2}{|c|}{ Light } & \multicolumn{2}{|c|}{ Medium } & \multicolumn{2}{|c|}{ Dark } \\
\hline & Rt. & Area \% & Rt. & Area\% & Rt. & Area\% & Rt. & Area\% \\
\hline Catechin & 2.42 & 6.63 & 2.43 & 7.41 & 2.46 & 7.05 & 2.48 & 4.80 \\
\hline P.oH Benzoic acid & 2.65 & 1.55 & 2.64 & 1.06 & 2.63 & 0.87 & 2.59 & 0.47 \\
\hline Chlorogenic acid & 2.73 & 35.11 & 2.73 & 21.74 & 2.73 & 8.80 & 2.73 & 7.37 \\
\hline Unknown & 2.85 & 7.40 & 2.15 & 0.39 & 2.14 & 0.83 & 2.15 & 0.26 \\
\hline Unknown & 3.30 & 0.91 & 2.32 & 1.12 & 2.27 & 0.68 & 2.38 & 1.80 \\
\hline Caffeic acid & 3.31 & 2.25 & 3.32 & 2.89 & 3.32 & 4.03 & 3.32 & 2.57 \\
\hline Syringic acid & 3.85 & 0.51 & 3.85 & 1.29 & 3.82 & 0.42 & 3.85 & 1.21 \\
\hline Caffeine & 4.02 & 3.55 & 4.02 & 3.61 & 4.00 & 2.28 & 4.02 & 3.49 \\
\hline Unknown & 4.36 & 14.04 & 4.37 & 27.48 & 4.37 & 25.37 & 4.36 & 40.74 \\
\hline Vanillic acid & 4.40 & 11.30 & 4.49 & 5.00 & 4.40 & 3.05 & 4.44 & 17.49 \\
\hline Unknown & 4.66 & 7.80 & 3.37 & 1.90 & 2.77 & 1.12 & 3.39 & 1.23 \\
\hline Unknown & 5.19 & 0.44 & 3.62 & 2.08 & 2.84 & 6.02 & 3.64 & 2.33 \\
\hline Unknown & 5.67 & 4.44 & 2.85 & 6.90 & 3.42 & 0.52 & 2.82 & 4.66 \\
\hline Unknown & 6.10 & 0.40 & 4.57 & 7.58 & 3.50 & 2.40 & 4.99 & 3.25 \\
\hline P. Coumaric acid & 6.23 & 0.26 & 6.25 & 0.47 & --- & --- & 6.24 & 0.55 \\
\hline Unknown & 6.30 & 0.11 & 4.97 & 3.18 & 3.63 & 1.67 & 5.36 & 1.20 \\
\hline Ferulic acid & 6.41 & 0.02 & 6.35 & 0.16 & --- & --- & 6.33 & 0.49 \\
\hline Unknown & 6.54 & 0.39 & 5.68 & 3.19 & 3.70 & 1.04 & 5.67 & 1.86 \\
\hline Unknown & 6.71 & 0.52 & 6.72 & 0.38 & 3.77 & 0.40 & 6.08 & 0.58 \\
\hline Salicylic acid & 6.85 & 0.35 & 6.86 & 0.04 & --- & --- & 6.87 & 0.31 \\
\hline Unknown & 6.99 & 0.37 & 7.03 & 0.72 & 4.12 & 0.41 & 7.03 & 1.17 \\
\hline Unknown & 7.59 & 0.28 & 8.55 & 0.22 & 4.16 & 0.31 & 7.58 & 1.38 \\
\hline Unknown & 8.70 & 0.60 & 8.62 & 0.10 & 4.18 & 0.26 & 8.53 & 0.42 \\
\hline Cinnamic acid & 8.82 & 0.11 & 8.89 & 0.13 & --- & --- & 8.82 & 0.13 \\
\hline Unknown & 9.07 & 0.69 & 9.06 & 0.14 & 4.20 & 0.25 & 8.61 & 0.27 \\
\hline Unknown & --- & --- & 9.11 & 0.82 & 4.23 & 0.30 & --- & --- \\
\hline Unknown & --- & --- & --- & --- & 4.41 & 25.50 & --- & --- \\
\hline Unknown & --- & --- & --- & --- & 4.97 & 2.98 & --- & --- \\
\hline Unknown & --- & --- & --- & --- & 5.28 & 0.31 & --- & --- \\
\hline Unknown & --- & --- & --- & --- & 5.35 & 1.02 & --- & --- \\
\hline Unknown & --- & --- & --- & --- & 5.68 & 2.12 & --- & --- \\
\hline
\end{tabular}

Chlorogenic acid was the main component of polyphenols and reached $35.11,21.74,8.80$ and $7.37 \%$ for green coffee beans, light, medium and dark roasted samples, respectively. Difference in concentrations of chlorogenic acid may be due to the effect of heat and time of roasting. Our findings about identification of polyphenols from green coffee beans, roasted coffee obtained from local market, roasted coffee in Laboratory for different periods i.e. 2 and 5 hrs. were in agreement with those reported by Naidu et al. (2007). They stated that green coffee contained polyphenols such as ferulic and caffeic acids, while chlorogenic acid was the main compound and their concentrations varied according to the species and roasting time.

Clifford (1999) and Daglia et al., (2000) concluded that every $1 \%$ reduction in dry matter, $8-10 \%$ of chlorogenic acid is lost subsequently. Green coffee beans had a higher chlorogenic acid content than roasted 
beans which was then reflected in higher antioxidant activity of green coffee beans as compared to roasted coffee beans.

\section{Antioxidant capacity determined by $\left(\mathrm{ABTS}^{+}\right)$cation radical :}

The capacity of caffeine and polyphenols extracts of green coffee, light, medium and dark roasted samples to scavenge the $\mathrm{ABTS}^{+}$radical were determined separately and compared with the reduction of ascorbic acid as control sample which is known as a strong reducing agent.

From table (4) and Figures (1 and 2), it could be seen that all extracts showed different degrees of inhibition capacity, but their capacities were less than ascorbic acid which had the maximum inhibition (91.41\%).

The same table indicated clearly that extracts of polyphenols for all samples had the absorbance values of $0.073,0.091,0.099$ and 0.108 with the values of $86.09,82.67,81.14$ and 79.43 as percentage of inhibition, for green coffee, light, medium and dark roasted samples, respectively.

On the contrary, the absorbance values of caffeine for all samples had the values of $0.119,0.131,0.142$ and 0.147 with the values of $77.34,75.05$, 72.95 and 72.00 as percentages of inhibition for green, light, medium and dark roasted samples, respectively.

Table (4): Reducing power of caffeine and polyphenols extracts from green, light, medium and dark roasted coffee beans.

\begin{tabular}{|c|l|c|c|}
\hline Extract & \multicolumn{1}{|c|}{ Sample } & Absorbance at 734 nm & \% Inhibition \\
\hline \multirow{4}{*}{ Caffeine } & Green & 0.119 & 77.34 \\
\cline { 2 - 4 } & Light for 2hrs & 0.131 & 75.05 \\
\cline { 2 - 4 } & Medium for 5hrs & 0.142 & 72.95 \\
\cline { 2 - 4 } Dark (local market) & 0.147 & 72.00 \\
\hline \multirow{3}{*}{ Polyphenols } & Green & 0.073 & 86.09 \\
\cline { 2 - 4 } & Light for 2hrs & 0.091 & 82.67 \\
\cline { 2 - 4 } & Medium for 5hrs & 0.099 & 81.14 \\
\cline { 2 - 4 } & Dark (local market) & 0.108 & 79.43 \\
\hline
\end{tabular}

Finally it could be concluded that all extracts of polyphenols had a higher inhibition capacity as percentages compare with caffeine. Also, polyphenols and caffeine extracts from green coffee had the highest values of inhibition as percentage than those of all roasted samples.

From the same table it could be observed that polyphenols and caffeine extracts of roasted coffee at the market (dark) had the lowest values of inhibition, this may be attributed to the effect of high temperature which used in roasting. Del Castillo et al. (2002) reported that during the roasting process, the naturally occurring polyphenolic constituents are transformed to a complex mixture of Maillard reaction products. Castellucio et al. (1995) when they used the $\mathrm{ABTS}^{+}$method, stated that light or medium roasted coffee have been shown higher antioxidant activity, which was in agreement with our finding. 
Tadros, L.K. et al.

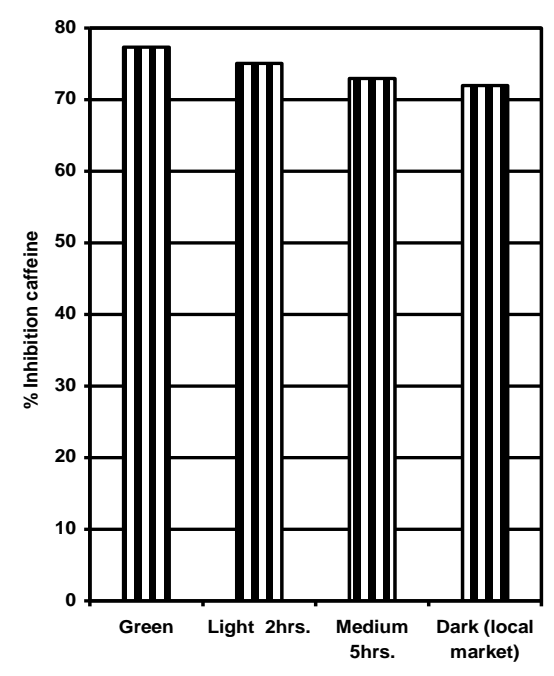

Fig.(1): Antioxidant activity of caffeine extract of green and roasted coffee beans by the reaction with $\left(\mathrm{ABTS}^{+}\right)$cation radical.

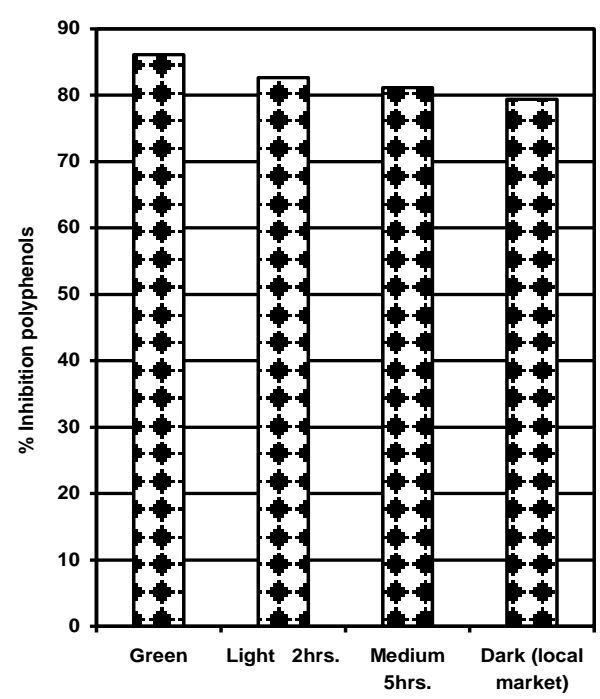

Fig. (2): Antioxidant activity of polyphenols extract of green and roasted coffee beans by the reaction with $\left(\mathrm{ABTS}^{+}\right)$cation radical.

\section{Caffeine and polyphenols extracted from coffee beans as natural} antioxidants:

This trial was carried out to evaluate the effect of caffeine and polyphenols extracted from roasted coffee beans obtained from local market on the inhibition of lipids peroxidation. Peroxide value was taken as a good parameter to evaluate the stability of sunflower oil during incubation at $60{ }^{\circ} \mathrm{C}$ for 20 days. Peroxide value for fresh sunflower oil sample was 6.30 meq $\mathrm{O}_{2} / \mathrm{kg}$ oil.

Tables (5, 6 and 7), show the peroxide values of control and treated samples with $100 \mathrm{ppm}$ BHT as synthetic antioxidant, caffeine, polyphenols and mixture of caffeine and polyphenols methanolic extract as natural antioxidants in different concentrations, i.e. 1000, 3000 and $6000 \mathrm{ppm}$. Obtained data of peroxide values were divided by the peroxide value of fresh sunflower oil sample (6.30).

From the same table, it could be concluded that calculated peroxide value for the untreated sample (control) increased gradually from 1.09 after one day to a maximum value of 286 after 13 days from the beginning of incubation at $60^{\circ} \mathrm{C}$.

Peroxide values of the control sample were continually decreased after 14 days till the end of the experiment i.e. $(259.84,215.81,194.35,165.58$, $158.61,154.06$ and 111.25 after 14, 15, 16, 17, 18, 19 and 20 days, respectively). 
Table (5): Peroxide values of control and treated samples with BHT and caffeine in different concentrations divided by the peroxide value of fresh sunflower oil (6.30) during incubation at $60{ }^{\circ} \mathrm{C}$ for 20 days.

\begin{tabular}{|c|c|c|c|c|c|}
\hline \multirow{2}{*}{ Days } & \multirow{2}{*}{ Control } & \multirow{2}{*}{ BHT (ppm) 100 } & \multicolumn{3}{|c|}{ Caffeine (ppm) } \\
\cline { 4 - 6 } & & & $\mathbf{1 0 0 0}$ & $\mathbf{3 0 0 0}$ & $\mathbf{6 0 0 0}$ \\
\hline $\mathbf{1}$ & 1.09 & 1.09 & 1.09 & 1.09 & 1.09 \\
\hline $\mathbf{2}$ & 4.57 & 2.35 & 2.83 & 2.72 & 2.37 \\
\hline $\mathbf{3}$ & 14.87 & 4.86 & 11.73 & 10.74 & 9.79 \\
\hline $\mathbf{4}$ & 22.06 & 7.62 & 21.35 & 19.71 & 19.59 \\
\hline $\mathbf{5}$ & 30.95 & 9.64 & 29.67 & 22.73 & 21.42 \\
\hline $\mathbf{6}$ & 45.96 & 12.44 & 44.71 & 43.07 & 42.45 \\
\hline $\mathbf{7}$ & 49.97 & 18.39 & 47.30 & 45.44 & 40.40 \\
\hline $\mathbf{8}$ & 74.01 & 19.65 & 71.30 & 69.99 & 68.54 \\
\hline $\mathbf{9}$ & 87.09 & 22.93 & 75.30 & 66.12 & 63.20 \\
\hline $\mathbf{1 0}$ & 147.99 & 23.09 & 146.88 & 145.58 & 129.76 \\
\hline $\mathbf{1 1}$ & 169.07 & 23.68 & 152.22 & 161.83 & 144.70 \\
\hline $\mathbf{1 2}$ & 251.31 & 27.77 & 198.90 & 199.32 & 162.37 \\
\hline $\mathbf{1 3}$ & 286.08 & 36.22 & 224.46 & 219.70 & 213.25 \\
\hline $\mathbf{1 4}$ & 259.84 & 32.14 & 254.13 & 233.11 & 233.99 \\
\hline $\mathbf{1 5}$ & 215.81 & 46.20 & 206.38 & 204.86 & 200.39 \\
\hline $\mathbf{1 6}$ & 194.35 & 49.82 & 174.46 & 109.48 & 160.43 \\
\hline $\mathbf{1 7}$ & 165.58 & 58.61 & 115.12 & 103.87 & 95.57 \\
\hline $\mathbf{1 8}$ & 158.61 & 58.66 & 154.27 & 144.83 & 137.21 \\
\hline $\mathbf{1 9}$ & 154.06 & 94.32 & 131.74 & 126.06 & 113.37 \\
\hline $\mathbf{2 0}$ & 111.25 & 51.82 & 102.73 & 100.26 & 97.46 \\
\hline
\end{tabular}

Table (6): Peroxide values of control and treated samples with BHT and polyphenols in different concentrations divided by the peroxide value of fresh sunflower oil (6.30) during incubation at $60{ }^{\circ} \mathrm{C}$ for 20 days.

\begin{tabular}{|c|c|c|c|c|c|}
\hline \multirow{2}{*}{ Days } & \multirow{2}{*}{ Control } & \multirow{2}{*}{ BHT (ppm) 100 } & \multicolumn{3}{|c|}{ Polyphenol (ppm) } \\
\cline { 4 - 6 } & & & $\mathbf{1 0 0 0}$ & $\mathbf{3 0 0 0}$ & $\mathbf{6 0 0 0}$ \\
\hline $\mathbf{1}$ & 1.09 & 1.09 & 1.09 & 1.09 & 1.09 \\
\hline $\mathbf{2}$ & 4.57 & 2.35 & 2.86 & 2.58 & 2.56 \\
\hline $\mathbf{3}$ & 14.87 & 4.86 & 9.77 & 9.22 & 6.73 \\
\hline $\mathbf{4}$ & 22.06 & 7.62 & 13.82 & 12.47 & 8.93 \\
\hline $\mathbf{5}$ & 30.95 & 9.64 & 13.48 & 10.82 & 9.89 \\
\hline $\mathbf{6}$ & 45.96 & 12.44 & 20.49 & 18.41 & 16.63 \\
\hline $\mathbf{7}$ & 49.97 & 18.39 & 27.62 & 26.54 & 24.79 \\
\hline $\mathbf{8}$ & 74.01 & 19.65 & 40.82 & 38.99 & 38.41 \\
\hline $\mathbf{9}$ & 87.09 & 22.93 & 71.82 & 62.43 & 59.43 \\
\hline $\mathbf{1 0}$ & 147.99 & 23.09 & 98.02 & 86.94 & 71.54 \\
\hline $\mathbf{1 1}$ & 169.07 & 23.68 & 119.63 & 93.64 & 92.11 \\
\hline $\mathbf{1 2}$ & 251.31 & 27.77 & 186.21 & 176.71 & 155.59 \\
\hline $\mathbf{1 3}$ & 286.08 & 36.22 & 230.43 & 203.66 & 196.94 \\
\hline $\mathbf{1 4}$ & 259.84 & 32.14 & 220.97 & 212.17 & 207.53 \\
\hline $\mathbf{1 5}$ & 215.81 & 46.20 & 202.51 & 191.14 & 188.87 \\
\hline $\mathbf{1 6}$ & 194.35 & 49.82 & 163.07 & 156.16 & 151.93 \\
\hline $\mathbf{1 7}$ & 165.58 & 58.61 & 127.27 & 103.27 & 99.67 \\
\hline $\mathbf{1 8}$ & 158.61 & 58.66 & 131.29 & 127.66 & 122.07 \\
\hline $\mathbf{1 9}$ & 154.06 & 94.32 & 111.29 & 106.47 & 89.65 \\
\hline $\mathbf{2 0}$ & 111.25 & 51.82 & 105.60 & 94.93 & 84.95 \\
\hline
\end{tabular}


Tadros, L.K. et al.

Resultant decrease in peroxide values may be attributed to the decomposition of the formed peroxides to short chain aldehydes and carboxylic acids (Lea, 1962).

Treated sample with BHT in concentration of $100 \mathrm{ppm}$ showed a remarkable effect for antioxidative activity where, peroxide value was 2.35 after two days of incubation while, the control sample was 4.57. The percentages of reduction in peroxide value when compared with untreated sample (control) at the same period of incubation represented $48.58 \%$. Peroxide values of treated samples with caffeine in concentrations of 1000 , 3000 and $6000 \mathrm{ppm}$ for the same period were 2.83, 2.72 and 2.37, respectively.

Table (7): Peroxide values of control and treated samples with BHT and mixture containing caffeine and polyphenols $1: 1$ in different concentrations divided by the peroxide value of fresh sunflower oil (6.30) during incubation at $60^{\circ} \mathrm{C}$ for 20 days.

\begin{tabular}{|c|c|c|c|c|c|}
\hline \multirow{2}{*}{ Days } & \multirow{2}{*}{ Control } & \multirow{2}{*}{ BHT (ppm) $\mathbf{1 0 0}$} & \multicolumn{3}{|c|}{ Caffeine and polyphenols (1:1) (ppm) } \\
\cline { 4 - 6 } & & & $\mathbf{1 0 0 0}$ & $\mathbf{3 0 0 0}$ & $\mathbf{6 0 0 0}$ \\
\hline $\mathbf{1}$ & 1.09 & 1.09 & 1.09 & 1.09 & 1.09 \\
\hline $\mathbf{2}$ & 4.57 & 2.35 & 3.96 & 3.69 & 3.36 \\
\hline $\mathbf{3}$ & 14.87 & 4.86 & 10.28 & 8.28 & 8.05 \\
\hline $\mathbf{4}$ & 22.06 & 7.62 & 15.50 & 13.39 & 12.04 \\
\hline $\mathbf{5}$ & 30.95 & 9.64 & 24.88 & 22.44 & 20.01 \\
\hline $\mathbf{6}$ & 45.96 & 12.44 & 39.80 & 36.52 & 32.51 \\
\hline $\mathbf{7}$ & 49.97 & 18.39 & 45.48 & 35.41 & 35.15 \\
\hline $\mathbf{8}$ & 74.01 & 19.65 & 52.81 & 47.58 & 47.14 \\
\hline $\mathbf{9}$ & 87.09 & 22.93 & 58.67 & 57.45 & 56.49 \\
\hline $\mathbf{1 0}$ & 147.99 & 23.09 & 138.29 & 118.17 & 111.55 \\
\hline $\mathbf{1 1}$ & 169.07 & 23.68 & 166.97 & 148.07 & 138.63 \\
\hline $\mathbf{1 2}$ & 251.31 & 27.77 & 243.63 & 210.97 & 206.57 \\
\hline $\mathbf{1 3}$ & 286.08 & 36.22 & 277.24 & 263.01 & 254.74 \\
\hline $\mathbf{1 4}$ & 259.84 & 32.14 & 253.58 & 241.69 & 232.53 \\
\hline $\mathbf{1 5}$ & 215.81 & 46.20 & 194.35 & 180.22 & 176.27 \\
\hline $\mathbf{1 6}$ & 194.35 & 49.82 & 186.55 & 161.29 & 155.30 \\
\hline $\mathbf{1 7}$ & 165.58 & 58.61 & 142.40 & 141.32 & 138.60 \\
\hline $\mathbf{1 8}$ & 158.61 & 58.66 & 144.13 & 141.38 & 140.46 \\
\hline $\mathbf{1 9}$ & 154.06 & 94.32 & 151.77 & 143.13 & 135.16 \\
\hline $\mathbf{2 0}$ & 111.25 & 51.82 & 109.15 & 103.13 & 100.98 \\
\hline
\end{tabular}

For further incubation time, peroxide value of treated sample with BHT raised gradually. For instance, after 8 days of incubation, peroxide value was 19.65 , this value still less than the peroxide value of the untreated sample (control) at the same period. The percentage of reduction represented 73.45 $\%$. After 14 days of incubation the percentage of reduction in peroxide value for treated sample with BHT (100 ppm) was $87.63 \%$ compared with untreated sample for the same period (control). The addition of caffeine to sunflower oil in concentrations of 1000, 3000 and $6000 \mathrm{ppm}$ retarded the auto-oxidation of the oil samples under investigation. These reductions represented $38.07,40.48$ and $48.14 \%$, respectively compared with untreated sample (control) after 2 days of incubation. For further incubation time, percentages of reduction represented $3.66,5.43,7.4 ; 21.53,23.2$ and 25.46 for oil samples treated with 1000, 3000 and 6000 ppm caffeine and incubated 
for 8 and 13 days, respectively. When the polyphenols extracted from roasted coffee beans were added to the oil samples, the percentage of reduction in peroxide values were $37.41,43.54,43.98 ; 44.84,47.32$, 48.10; 19.45, 28.81 and 31.16 for the concentrations of 1000,3000 and $6000 \mathrm{ppm}$, when incubated for 2, 8 and 13 days, respectively. On the other hand as shown in table (7), oil samples treated with the same previous concentrations of mixture containing (caffeine and polyphenols in the ratio of $1: 1 \mathrm{w} / \mathrm{w}$ ) and incubated for 2, 8 and 13 days led to a decrease in the peroxide values. These percentages of decrease were as follows: 13.34, 19.26, 26.48; 28.64, $35.71,36.30 ; 3.10,8.06$ and $11.00 \%$, respectively.

Tables $(8,9$ and 10$)$ showed the protection index (PI) of caffeine, polyphenols and mixture of both caffeine and polyphenols extracted from roasted coffee beans, in different concentrations compared with $100 \mathrm{ppm}$ BHT during incubatio for 20 days.

It could be noticed that the protection index of BHT was $100 \%$ for all samples during the experiment periods. Obtained data indicated that the protection index for treated samples with extracts under investigation were decreased gradually to reach the lowest values after 10 days of incubation which represented 0.89 and $1.93 \%$ for samples treated with caffeine in the concentrations of 1000 and 3000 ppm, respectively. Meanwhile, the lowest value of protection index for sample treated with $6000 \mathrm{ppm}$ was $9.09 \%$ after 15 days. On the other hand, samples treated with polyphenols had the values of protection indexes after 15 days as follows: $7.84,14.55$ and $15.88 \%$ for the concentrations of 1000,3000 and 6000 ppm, respectively.

Table (8): Protection index (PI \%) of caffeine extract of roasted coffee beans in different conce ntrations compared with $100 \mathrm{ppm}$ BHT during incubation at $60^{\circ} \mathrm{C}$ for 20 days.

\begin{tabular}{|c|c|c|c|c|}
\hline \multirow{2}{*}{ Days } & $\begin{array}{c}\text { BHT 100 } \\
\text { (ppm) }\end{array}$ & \multicolumn{3}{|c|}{ Caffeine (ppm) } \\
\cline { 3 - 5 } & 100 & 1000 & $\mathbf{3 0 0 0}$ & $\mathbf{6 0 0 0}$ \\
\hline $\mathbf{1}$ & 100 & 78.38 & 100 & 100 \\
\hline $\mathbf{2}$ & 100.34 & 99.09 \\
\hline $\mathbf{3}$ & 100 & 31.36 & 41.25 & 49.26 \\
\hline $\mathbf{4}$ & 100 & 4.91 & 16.06 & 17.17 \\
\hline $\mathbf{5}$ & 100 & 6.01 & 38.57 & 44.72 \\
\hline $\mathbf{6}$ & 100 & 3.27 & 8.62 & 10.46 \\
\hline $\mathbf{7}$ & 100 & 8.48 & 14.34 & 30.31 \\
\hline $\mathbf{8}$ & 100 & 5.00 & 7.40 & 10.06 \\
\hline $\mathbf{9}$ & 100 & 18.37 & 32.69 & 37.24 \\
\hline $\mathbf{1 0}$ & 100 & 0.89 & 1.93 & 14.60 \\
\hline $\mathbf{1 1}$ & 100 & 11.59 & 4.98 & 16.76 \\
\hline $\mathbf{1 2}$ & 100 & 23.45 & 23.26 & 39.79 \\
\hline $\mathbf{1 3}$ & 100 & 24.66 & 26.57 & 29.15 \\
\hline $\mathbf{1 4}$ & 100 & 2.51 & 11.74 & 11.35 \\
\hline $\mathbf{1 5}$ & 100 & 5.56 & 6.46 & 9.09 \\
\hline $\mathbf{1 6}$ & 100 & 13.76 & 58.72 & 23.47 \\
\hline $\mathbf{1 7}$ & 100 & 47.18 & 57.69 & 65.45 \\
\hline $\mathbf{1 8}$ & 100 & 4.33 & 13.79 & 21.41 \\
\hline $\mathbf{1 9}$ & 100 & 37.37 & 46.87 & 68.12 \\
\hline $\mathbf{2 0}$ & 100 & 14.34 & 18.50 & 23.19 \\
\hline
\end{tabular}


Tadros, L.K. et al.

The lowest values of PI were 1.44, 7.97 and $11.99 \%$ for the samples treated with the mixture of caffeine and polyphenols after 11 days for the concentration of $1000 \mathrm{ppm}$ and 14 days for the concentrations of 3000 and $6000 \mathrm{ppm}$, respectively. Then the values increased gradually to reach the highest values of $68.12,91.04$ and $31.64 \%$ for samples treated with caffeine, polyphenols and mixture of both in the concentration of $6000 \mathrm{ppm}$ after 19 days of incubation, respectively.

It seems that the activity of BHT to inhibit peroxidation of sunflower oil is stronger than those of caffeine and polyphenols of coffee beans extracts, in all used concentrations.

Data in tables (8, 9 and 10) indicated that high concentrations of caffeine, polyphenols and mixture of both extracts had stronger effect on the antioxidative activity than the lower concentrations i.e. 6000>3000>1000 $\mathrm{ppm}$. Also, the effect of polyphenols extract was stronger than the mixture and caffeine extracts i.e. polyphenols extract>mixture>caffeine. Similar results were obtained by many investigators, who reported that the natural antioxidants have lower antioxidant activities than synthetic antioxidants (Tsuda et al., 1993; Alaiz et al., 1995; Emmons and Peterson 1999 and Amarowicz et al., 2000).

Table (9): Protection index (PI \%) of polyphenols extract of roasted coffee beans in different concentrations compared with 100 ppm BHT during incubation at $60^{\circ} \mathrm{C}$ for 20 days.

\begin{tabular}{|c|c|c|c|c|}
\hline \multirow{2}{*}{ Days } & BHT 100 & \multicolumn{3}{|c|}{ Polyphenols (ppm) } \\
\cline { 3 - 5 } & (ppm) & $\mathbf{1 0 0 0}$ & $\mathbf{3 0 0 0}$ & $\mathbf{6 0 0 0}$ \\
\hline $\mathbf{1}$ & 100 & 100 & 100 & 100 \\
\hline $\mathbf{2}$ & 100 & 77.02 & 89.64 & 90.54 \\
\hline $\mathbf{3}$ & 100 & 50.95 & 56.44 & 81.32 \\
\hline $\mathbf{4}$ & 100 & 57.06 & 66.41 & 90.93 \\
\hline $\mathbf{5}$ & 100 & 81.98 & 94.46 & 98.83 \\
\hline $\mathbf{6}$ & 100 & 75.98 & 82.19 & 87.50 \\
\hline $\mathbf{7}$ & 100 & 70.77 & 74.19 & 79.73 \\
\hline $\mathbf{8}$ & 100 & 61.06 & 64.42 & 65.49 \\
\hline $\mathbf{9}$ & 100 & 23.80 & 38.44 & 43.11 \\
\hline $\mathbf{1 0}$ & 100 & 40.01 & 48.88 & 61.21 \\
\hline $\mathbf{1 1}$ & 100 & 34.01 & 51.88 & 52.93 \\
\hline $\mathbf{1 2}$ & 100 & 29.12 & 33.37 & 42.82 \\
\hline $\mathbf{1 3}$ & 100 & 22.27 & 32.99 & 35.68 \\
\hline $\mathbf{1 4}$ & 100 & 17.07 & 20.94 & 22.97 \\
\hline $\mathbf{1 5}$ & 100 & 7.84 & 14.55 & 15.88 \\
\hline $\mathbf{1 6}$ & 100 & 21.64 & 26.42 & 29.35 \\
\hline $\mathbf{1 7}$ & 100 & 50.75 & 55.26 & 70.98 \\
\hline $\mathbf{1 8}$ & 100 & 27.33 & 30.97 & 36.56 \\
\hline $\mathbf{1 9}$ & 100 & 44.84 & 85.02 & 91.04 \\
\hline $\mathbf{2 0}$ & 100 & 9.51 & 27.46 & 44.25 \\
\hline
\end{tabular}


Duarte et al. (2005) reported that the BHT showed a maximum inhibition of guaiacol oxidation of $56.94 \%$ and coffee brew maximum inhibition was $43.79 \%$. Also, they demonstrated that the coffee beverages inhibit lipid damage, and they attributed this effect to the action of polyphenols. Richelle et al. (2001) also observed that coffee brews can protect against lipid oxidation. In an assay involving measuring low - density lipoproteeins oxidation, they demonstrated a decrease in the antioxidant capacity of coffee brews with an increase in the extent of roasting. They suggest that this capacity was not due to a single polyphenolic compound, but returned to the action of several polyphenolic constituents. Nicoli et al. (1997) found that coffee brews can suppress lipid oxidation in the Rancimat test with the maximum activity in the medium - dark roasted coffee. Daglia et al. (2000) analyzing the coffee brew protective capacity against rat liver microsomal lipid peroxidation, found that all of the roasted samples gave complete protection.

Finally, it can be concluded that the natural antioxidants may be have lower antioxidant activities than synthetic antioxidants, but using the natural sources as antioxidants are more safety than BHT for human.

Table (10): Protection index (PI \%) for mixture containing caffeine and polyphenols (1:1) in different concentrations compared with $100 \mathrm{ppm}$ BHT during incubation at $60^{\circ} \mathrm{C}$ for 20 days.

\begin{tabular}{|c|c|c|c|c|}
\hline \multirow{2}{*}{ Days } & BHT 100 & \multicolumn{3}{|c|}{ Caffeine and polyphenols (1:1) (ppm) } \\
\cline { 3 - 5 } & $(\mathbf{p p m})$ & $\mathbf{1 0 0 0}$ & $\mathbf{3 0 0 0}$ & $\mathbf{6 0 0 0}$ \\
\hline $\mathbf{1}$ & 100 & 100 & 100 & 100 \\
\hline $\mathbf{2}$ & 100 & 27.48 & 39.64 & 54.50 \\
\hline $\mathbf{3}$ & 100 & 45.85 & 65.83 & 68.13 \\
\hline $\mathbf{4}$ & 100 & 45.43 & 60.04 & 69.39 \\
\hline $\mathbf{5}$ & 100 & 28.48 & 39.93 & 51.34 \\
\hline $\mathbf{6}$ & 100 & 18.38 & 28.16 & 40.13 \\
\hline $\mathbf{7}$ & 100 & 14.22 & 46.11 & 46.93 \\
\hline $\mathbf{8}$ & 100 & 39.00 & 48.62 & 49.43 \\
\hline $\mathbf{9}$ & 100 & 44.30 & 46.20 & 47.70 \\
\hline $\mathbf{1 0}$ & 100 & 7.77 & 23.88 & 29.18 \\
\hline $\mathbf{1 1}$ & 100 & 1.44 & 14.44 & 20.94 \\
\hline $\mathbf{1 2}$ & 100 & 3.44 & 18.05 & 20.01 \\
\hline $\mathbf{1 3}$ & 100 & 3.54 & 9.23 & 12.54 \\
\hline $\mathbf{1 4}$ & 100 & 2.75 & 7.97 & 11.99 \\
\hline $\mathbf{1 5}$ & 100 & 12.65 & 20.98 & 23.31 \\
\hline $\mathbf{1 6}$ & 100 & 5.40 & 22.87 & 27.02 \\
\hline $\mathbf{1 7}$ & 100 & 21.67 & 22.68 & 25.22 \\
\hline $\mathbf{1 8}$ & 100 & 14.49 & 17.24 & 18.16 \\
\hline $\mathbf{1 9}$ & 100 & 3.83 & 18.30 & 31.64 \\
\hline $\mathbf{2 0}$ & 100 & 3.53 & 13.66 & 17.28 \\
\hline
\end{tabular}




\section{REFERENCES}

A.O.A.C. Association of Official Analytical Chemists (2000). Official Methods of Analysis. $17^{\text {th }}$ ed. The Association, Washington DC. USA.

Alaiz, M.; Zamora, R. and Hidalgo, F.J. (1995). Natural antioxidants produced in oxidized lipid/amino acid browning reactions. J. Amer. Oil Chem. Soc., 72: 1571-1575.

Amarowicz, R.; Naczk, M. and Shahidi, F. (2000). Antioxidant activity of various fractions of non-tannin phenolics of canola hulls. J. Agric. Food chem., 48: 2755.

Anese, M. and Nicoli, M.C. (2003). Antioxidant properties of ready-to drink coffee brews. J. of Agric. and Food Chem., 51: 942-946.

Ben-Hammouda, M.; Kremer, R.J.; Minor, H.C. and Sarwar, M. (1995). A chemical basis for differential allelopathic potential of sorghum hybrids on wheat. J. Chem. Ecol., 21: 775-786.

Castellucio, C.; Pagango, G.; Melikian, N.; Bolwell, G.P.; Pridham, J. and Sampson, J. (1995). Antioxidant potential of intermediates in phenylpropanoid metabolism in higher plants.FEBS Letters, 368: 188192.

Clarke, R.J. (1985). Water and mineral contents. In R.J. Clarkc and R. Macrac (Eds.), coffee vol. 1: Chemistry (pp. 42-82). London: Elscvicr Applied Science.

Clifford, M.N. (1999). Chlorogenic acids and other cinnamates-nature, occurrence and dietary burden. J. of the Science of Food and Agriculture, 70: 362-372.

Daglia, M.; Papetti, A.; Gregotti, C.; Berte, F. and Gazzani, G. (2000). In vitro antioxidant and ex vivo protective activities of green and roasted coffee. J. of Agric. and Food Chem., 48: 1449-1454.

Del Castillo, M.D.; Ames, J.M. and Gordon, M.H. (2002). Effect of roasting on the antioxidant activity of coffee brews. J. of Agricultural and Food Chemistry, 50: 3698-3703.

Delgado-Andrade, C. and Morales, F.J. (2005). Unraveling the contribution of melanoidins to the antioxidant activity of coffee brews. J. of Agric. and Food Chem., 53: 1403-1407.

Duarte, S.M.da.S.; Abreu, C.M.P.; Menezes, H.C.; Santos, M.H. and Gouvea, C.M.C. (2005). Effect of processing and roasting on the antioxidant activity of coffee brews. Cienc. Tecnol. Aliment., Campinas, 25(2): 387393.

Emmons, C.L. and Peterson, D.M. (1999). Antioxidant activity and phenolic contents of oat goats and hulls. Cereal Chem., 76, 902.

Harborne, J.B. (1988). Phytochemical methods, $2^{\text {nd }}$ ed. Published in USA by Chapman and Hall 29, west $35^{\text {th }}$ street, New York.

Imaida, K.; Fukushima, S.; Shirui, T.; Ohtani, M.; Nakanishi, K. and Ito, N. (1983). Promoting actions of butylated hydroxy anisole and butylated hydroxy toluene on 2-stage urinary bladder carcinogensis and inhibition of c-glutamyl transpeptidase-positive foci development in the liver of rats, carcinogenesis, 4, 895-899. 
IUPAC (1987). Standard methods for the analysis of oil, fats and derivatives. Blackwell Scientific Publications, London.

Lea, C.H. (1962). The oxidative determination of food lipids. Symposium on foods : Lipids and their oxidation. The AVI Publishing Company, INC. London.

Leitzmann, M.F.; Stamplet, M.J.; Willet, W.C.; Spiegelman, D.; Colditz, G.A.; Giovannucci, E.L. (2007). Coffee intake is associated with lower risk of symptomatic gallstone disease in women. Gastroenterology, 123, 1823-1830. C.F. European commission, Directorate General Joint Research Center, 40: 1849-1854.

Macrae, R. (1985). Nitrogenous compounds. In R.J. Clarkc and R. Macrac (Eds.), coffee vol. 1: Chemistry (pp. 115-152) London: Elscvicr Applied Science.

Madhava Naidu, M.; Sulochanamma, G.; Sampathu, S.R. and Srinivas, P. (2008). Studies on extraction and antioxidant potential of green coffee. Food Chemistry, 107: 377-384.

Naidu, M.M.; Sulochanamma, G.; Sampathu, S.R. and Srinivas, P. (2007). Studies on extraction and antioxidant potential of green coffee. J. of Food Chem., 107: 377-384.

Nicoli, M.C.; Anese, M.; Manzocco, L. and Lerici, C.R. (1997). Antioxidant properties of coffee brews in relation to the roasting degree. Lebensmitell wissenschaft and Technologic, 30: 292-297.

Oliveira, L.S.; Franca, A.S.; Mendonca, J.C.F. and Barros-Junior, M.C. (2006). Proximate composition and fatty acids profile of green and roasted defective coffee beans. LWT, 39: 235-239.

Parliment, T.H. (2000). An overview of coffee roasting. In: Parliament, T.H., Ho, C.T., Schieberle, P. (Eds.), Caffeinated Beverages: Benefits, Physiological Effects and Chemistry. Amer. Chem. Soc., Washington. pp. 188-201.

Paulo Mazzafera (1999). Chemical composition of defective coffee beans. Food Chem., 64: 547-554.

Re, R.; Pellegrini, N.; Proteggente, A.; Pannala, A.; Yang, M. and Riceevans, C. (1999). Antioxidant activity applying an improved $\mathrm{ABTS}^{+}$radical. Cation decolorization assay. Free Radical Biology \& Medicine, 26: 1231-1237.

Richelle, M.; Tavazzi, L. and Offord, E. (2001). Comparison of the antioxidant activity of commonly consumed polyphenolic beverages (coffee, cocoa and tea) prepared per cup serving. J. of Agric. and Food Chem., 49: 3438-3442.

Sacchetti, G.; Mattia, C.D.; Pittia, P. and Mastrocola, D. (2009). Effect of roasting degree, equivalent thermal effect and coffee type on the radical scavenging activity of coffee brews and their phenolic fraction. J. of Food Engineering, 90: 74-80.

Singleton, V.L. and Rossi, J. (1965). Calorimetry of total phenolic with phosphomolybdic phosphotungstic acid agents. Amer. J. of Enol. \& Vitic., 16: 144-158. 
Tadros, L.K. et al.

Somoza, V.; Lindenmeier, M.; Wenzel, E.; Frank, O.; Erbersdobler, H.F. and Hofmann, T. (2003). Activity guided identification of a chemopreventive compound in coffee beverage using in vitro and in vivo techniques. J. of Agric. and Food Chem., 51: 6861-6869.

Stadler, R.H.; Varga, N.; Milo, C.; Schilter, B.; Arce Ver, F. and Welti, D.H. (2002). Alkylpyridinium 2. Isolation and quantification in roasted and ground coffees. J. of Agric. and Food Chem., 50: 1200-1206.

Steinhart, H.; Luger, R. and Piost, J. (2002). Antioxidative effect of coffee melanoidins. In: Proceedings of the $19^{\text {th }}$ International Scientific Colloquium on coffee, Paris: Association Scientifique Internationale du Cafê.

Summa, S.; Wenzl, T.; Brohee, M.; Mast, J.; De la Calle, B. and Anklam, E. (2006). Investigation of the correlation of the acrylamide content and the antioxidant activity of model cookies. J. of Agric. and Food Chem., 54: 853-859.

Tavani, A. and La-Vecchia, C. (2000). Coffee and cancer: A review of epidimiological studies. European J. of Cancer Prevention, 9: 241-256.

Tsuda, T.; Osawa, T.; Nakayama, T.; Kawakishi, S. and Oshima, K. (1993). Antioxidant activity of pea bean extract. J. Amer. Oil Chem. Soc., 70(9): 909-913.

Turatti, J.M. (2001). Extracâo caracterizacâo de ôlco de cafê. Simpôsio de pesquisa dos cafês do Brasil (2: 1533-1539). Vitôria (in portugucsc).

Tverdal, A. and Skurtveit, S. (2003). Coffee intake and mortality from liver cirrhosis. Anals of Epidemology, 13: 419-423.

Van Dam, R.M. and Feskens, E.J. (2002). Coffee consumption and risk of type diabetes mellitus. Lancet, 360: 1477-1478.

Yen, W.J.; Wang, B.S.; Chang, L.W. and Duh, P.D. (2005). Antioxidant properties of roasted coffee residues. J. of Agric. and Food Chem., 53: 2658-2663.

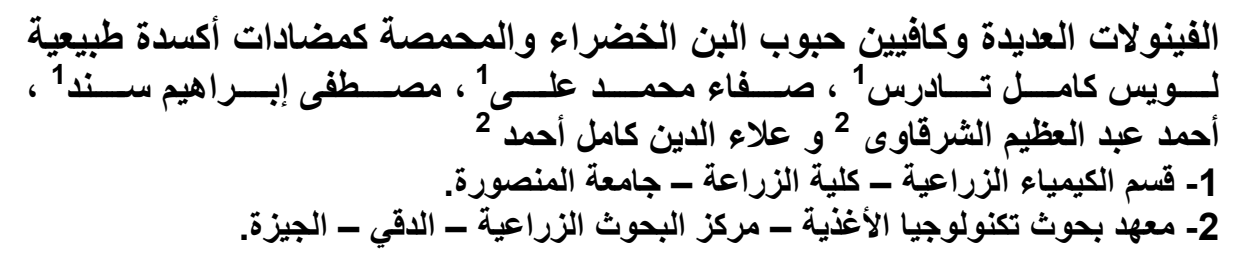

تم إستعمال أربعة عينات من البن وهى كالتالي : بن أخضر مطحون - بن تم تحميصسه في في في المي

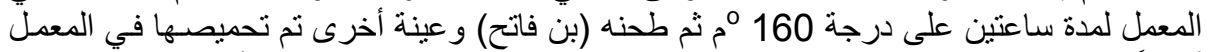

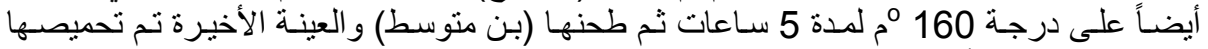

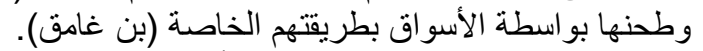

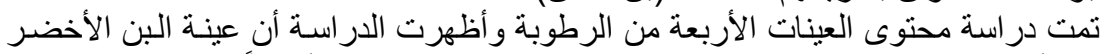

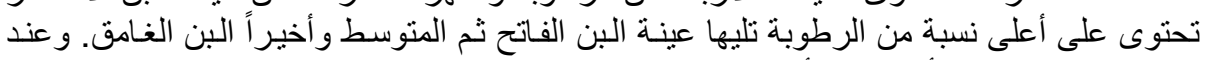

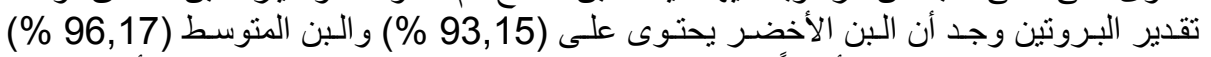

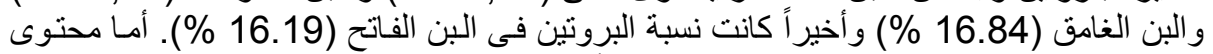
العينات من الزيت فكان كالتالي 13.91 \% و في الأخضر ، 16.67 \% فى البن المتوسط ، 15.91 


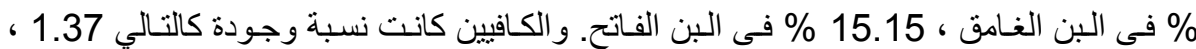
1.47 ، 1.55 ، 1.97 \% لكل من عينة البن الأخضر ، البن الفاتح ، البن المتوسط ثم البن الغامق

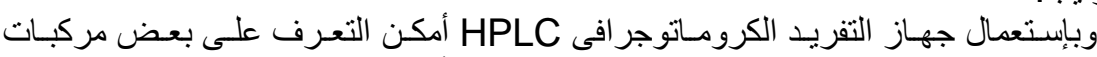
على الترتيب

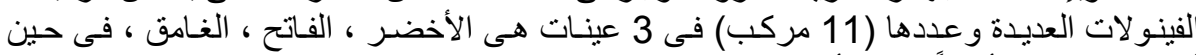

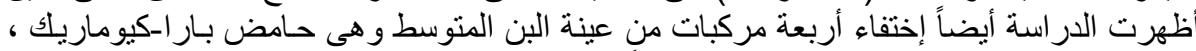

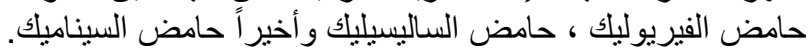

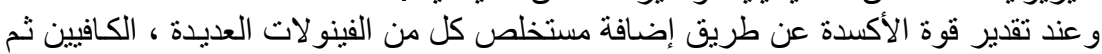

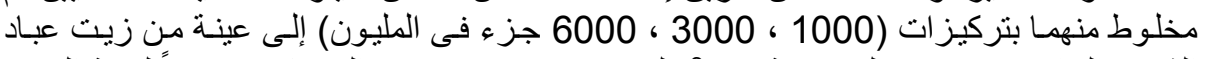

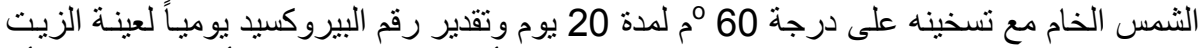

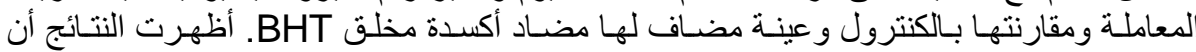

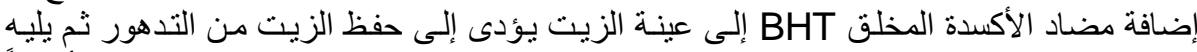

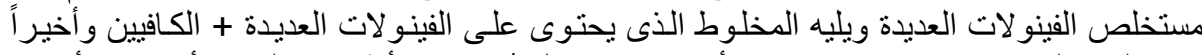

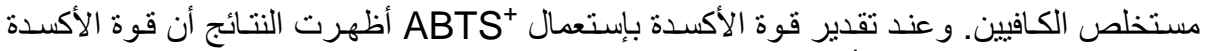
لمستخلص الفينو لات العديدة أقوى من مستخلص الكافيين.

كلية الزراعة - جامعة المنصورة كلية الزراعة - عين شمس جاعس المنورة
قام بتحكيم البحث

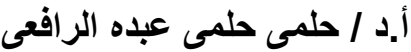
أ.د / فاروق جندى معوض عبده الرفع 